Portland State University

PDXScholar

\title{
A Cautionary Tale: Cryptic Sexual Size Dimorphism in a Socially Monogamous Passerine
}

Michael T. Murphy

Portland State University, murphym@pdx.edu

Follow this and additional works at: https://pdxscholar.library.pdx.edu/bio_fac

Part of the Biology Commons, and the Ornithology Commons Let us know how access to this document benefits you.

\section{Citation Details}

Murphy, Michael T., "A Cautionary Tale: Cryptic Sexual Size Dimorphism in a Socially Monogamous Passerine" (2007). Biology Faculty Publications and Presentations. 69.

https://pdxscholar.library.pdx.edu/bio_fac/69

This Article is brought to you for free and open access. It has been accepted for inclusion in Biology Faculty Publications and Presentations by an authorized administrator of PDXScholar. Please contact us if we can make this document more accessible: pdxscholar@pdx.edu. 


\title{
A CAUTIONARY TALE: CRYPTIC SEXUAL SIZE DIMORPHISM IN A SOCIALLY MONOGAMOUS PASSERINE
}

\author{
Michael T. Murphy ${ }^{1}$ \\ Department of Biology, P.O. Box 751, Portland State University, Portland, Oregon 97219, USA
}

Aвsтract.-Among socially monogamous birds, standard metrics suggest that males are only $\sim 5 \%$ larger than females. An untested assumption is that, with the exception of reproductive systems, males and females are scaled mirror images of one another. I used external morphological and skeletal data, and information on muscle mass and organ size, to test this assumption in a population of breeding Eastern Kingbirds (Tyrannus tyrannus). Male and female Eastern Kingbirds exhibited no differences in body mass or standard measures of size, except in a longer $(\sim 6 \%)$ wing chord and tail in males. However, keel length, a character rarely measured in the field, was $9.7 \%$ larger in males. In principal component analysis, overall body size (PC1) failed to differ between the sexes unless keel length was included. Analysis of 16 skeletal characters also showed that only the bones associated with flight were larger in males. However, the most significant differences between the sexes was that lean dry pectoral muscle mass (LDPMM) was nearly 30\% greater in males, whereas the alimentary tract was $27.5 \%$ heavier in females. Females also carried more fat. In both sexes, LDPMM scaled in a positive allometric manner with body mass (i.e., slope $>1.0$ ), but the significantly higher slope of males suggested especially strong selection for large muscle mass and, presumably, greater power generation during flight. Eastern Kingbirds thus exhibit pronounced cryptic sexual size dimorphism, but it is not clear whether natural or sexual selection is responsible. These data call for a broader perspective for measuring and a re-evaluation of sexual size dimorphism in other socially monogamous species. Received 20 December 2005, accepted 23 April 2006.

Key words: body size, Eastern Kingbird, keel length, muscle mass, sexual size dimorphism, Tyrannus tyrannus.

\section{Un Llamado de Atención: Dimorfismo Críptico en el Tamaño en un Paserino Socialmente Monógamo}

Resumen. - Entre las aves socialmente monógamas, las medidas estándar sugieren que los machos son sólo 5\% más grandes que las hembras. Una suposición que no se ha puesto a prueba es que, con excepción de los sistemas reproductivos, los machos y las hembras son imágenes especulares a escala uno del otro. Utilicé datos de morfología externa y del esqueleto e información sobre la masa muscular y el tamaño de los órganos para poner a prueba esta suposición en una población reproductiva de Tyrannus tyrannus. No existieron diferencias entre sexos en el peso corporal ni en medidas estándar del tamaño, excepto por una mayor longitud $(\sim 6 \%)$ de la cuerda alar y la cola en los machos. Sin embargo, la longitud de la quilla, un rasgo que rara vez es examinado en el campo, fue un 9.7\% mayor en los machos. En análisis de componentes principales, el tamaño corporal general (CP1) no difirió entre sexos a no

${ }^{1}$ E-mail: murphym@pdx.edu 
ser de que se incluyera la longitud de la quilla. Análisis de 16 caracteres esqueléticos también mostraron que sólo los huesos asociados con el vuelo fueron de mayor tamaño en los machos. Sin embargo, las diferencias más significativas entre los sexos fueron que la masa seca de músculo pectoral magro fue cerca del 30\% mayor en los machos y que el tracto digestivo fue un $27.5 \%$ más pesado en las hembras. Las hembras también presentaron más grasa. En ambos sexos, la masa seca de músculo pectoral magro se relacionó positivamente de forma alométrica con la masa corporal (i.e., pendiente $>$ 1.0), pero la pendiente de esta relación fue significativamente mayor en los machos, lo que sugiere la existencia de selección especialmente fuerte para presentar masa muscular elevada, y presumiblemente para presentar mayor capacidad de generar potencia durante el vuelo. En conclusión, T. tyrannus exhibe dimorfismo sexual crítpico en el tamaño, pero no está claro si éste es el resultado de selección natural o de selección sexual. Estos datos llaman la atención sobre la necesidad de tener una perspectiva más amplia para medir y re-evaluar el dimorfismo sexual en tamaño en otras especies socialmente monógamas.

BODY SIZE AND physiology are intimately linked, and as a consequence, size profoundly influences the behavior, ecology, and life histories of animals (see Calder 1984, Peters 1984, Zammuto 1986, Sæther 1989). Potential factors influencing the evolution of body size in birds are numerous, and a partial list includes climatically driven thermal and energetic stresses (Johnston and Selander 1971, Johnston and Fleischer 1981, E. C. Murphy 1985), energetic constraints during reproduction (e.g., Downhower 1976, Petrie 1983, Price 1984a), and social interactions. The latter range from mate-choice decisions (Petrie 1983, Price 1984b, Wagner 1999, Delestrade 2001) to both intra- (e.g., Petrie 1983, Piper and Wiley 1989, Radford and du Plessis 2004) and interspecific competition (Diamond 1975, Robinson and Terborgh 1995).

At the same time, a characteristic feature of body size is that the sexes generally differ. Sexual differences in size are common in all animal classes, with males generally being larger than females in endotherms (e.g., birds and mammals). Although intraspecific competition for resources (Johnston and Fleischer 1981, Temeles et al. 2000) or fertility selection for small female size during breeding (Downhower 1976, Price 1984a; see also Monaghan and Metcalfe 1986) may contribute to size dimorphism, the most widely accepted explanation for its existence is that sexual selection favors large males either as an outcome of male-male competition or female choice of mates (Darwin 1871). The most dimorphic are generally polygynous and lekking species, in which males are often 10-20\% larger than females (e.g., Webster 1992,
Székely et al. 2000), and in extreme cases, even twice their size (Wiley 1974). However, even among socially monogamous species, males are, on average, $~ 5 \%$ larger than females (e.g., Price 1984a, Delestrade 2001, Radford and du Plessis 2004).

It is also important to recognize that the sexes may differ in ways not reflected in either body mass or dimensions. A tacit assumption in all studies of sexual size dimorphism is that males and females are exact copies of one another that differ only in size, but as Hammond et al. (2000) showed (after controlling for greater male body mass), males of the polygynous Red Junglefowl (Gallus gallus) have smaller peritoneal and reproductive organs than females, but also possess a significantly larger heart, leg muscles, and lungs. Tree Swallows (Tachcycineta bicolor) showed fewer sexual differences, but males had larger pectoral muscles than females (Burness et al. 1998). Basal metabolic rate varies directly with the dry mass of muscle and vital organs (Daan et al. 1900, Piersma et al. 1996, Burness et al. 1998, Chappell et al. 1999, Hammond et al. 2000), and maximum oxygen consumption and aerobic scope scale directly with muscle mass (Chappell et al. 1999, Hammond et al. 2000). And on a behavioral level, large pectoral muscles enable greater flight acceleration (Veasey et al. 2000, Kullberg et al. 2002). The existence of "cryptic sexual size dimorphism" of organ size and muscle mass is a distinct possibility in species that are traditionally regarded as sexually monomorphic, and the implications are potential differences in energy needs, power output during locomotion, and behavior between the sexes. 
Here I re-examine data taken from Eastern Kingbirds (Tyrannus tyrannus) that I collected in 1983 (Murphy 1986) and test for the existence of cryptic sexual size dimorphism. I evaluate the degree to which standard morphological features characterize sexual size dimorphism, quantify differences in muscle mass and organ size, and ultimately conclude that standard practices for describing sexual size dimorphism fail to describe the level of sexual size dimorphism that exists in Eastern Kingbirds.

\section{Methods}

Field methods are detailed elsewhere (Murphy 1986), but briefly, I collected (mostly using a 0.22 caliber rifle with "dust shot") 31 female and 27 male Eastern Kingbirds in Douglas County, Kansas, between 4 May and 14 July 1983. Most birds (25 females and 19 males) were associated with nests and were known to be resident breeders. I recorded standard body measurements (see Murphy 1986 and below), and I also recorded keel length (straight-line distance from base of furcular depression [juncture of clavicles] to base of sternum). I measured keel length because the major flight muscles (pectoralis major and supracoracoideus) attach to the sternum and keel. My intent at the time was to investigate the possibility that reproductive traits of females varied with endogenous nutrient reserves stored in pectoral muscle. The collected birds were given an identifying number, double-bagged, and frozen until they were analyzed three to four months later. Collection numbers from the field were replaced by Kansas University Museum of Natural History specimen numbers (80262-80314) by a museum worker, and only after the analyses were completed did I match my collection numbers with the museum specimen numbers.

In the laboratory, I reweighed each bird, removed its entire plumage, reweighed the defeathered carcass and, by subtraction, determined plumage weight (omitting 2 males and 1 female whose plumages were soaked with blood). The skin and all subcutaneous fat were removed and weighed as one. The major flight muscles (pectoralis major and supracoracoideus $=$ the pectoral muscle mass $[\mathrm{PMM}]$ ) were then carefully excised from the right side of the body and weighed. I removed and weighed the proventriculus and gizzard and small and large intestine as one (contents removed from the stomach), weighed and measured the length and width of the testes, and weighed the ovary and oviduct.

Most of the remaining muscle was removed and weighed, and all other organs were removed from the carcass. The skeleton and small amounts of muscle that could not be removed was then dried and weighed before maceration. Following maceration, I dried and reweighed the skeleton, and determined the mass of the attached muscle and connective tissue by subtraction. All individual muscle masses were similarly dried and weighed until they reached constant values. Thus, I determined the dry mass of the PMM (doubled to account for the side that I did not process), and of the entire musculature (= total muscle mass [TMM]) and skeleton, plus the wet mass of the skin and associated fat, stomach, and gonads. I then ground the dried PMM and other muscles to a powder with mortar and pestle and extracted intramuscular fat from 0.5- to 0.8-g samples of each, using petroleum ether in a Soxhlet apparatus. I reran 12 samples to establish that the extraction time $(4 \mathrm{~h})$ was sufficient to remove all intramuscular fat and derived total intramuscular fat content for the PMM and TMM, based on the percentage fat of each bird's sample. Lean dry pectoral muscle mass (LDPMM) and lean dry total muscle mass (LDTMM) were determined by subtracting each individual's pectoral and total intramuscular fat content (g) from the appropriate mass of dry muscle.

Mature feathers are dead tissue; skin, fat, and bone exhibit very low metabolic activity. Therefore, to determine the mass of the total lean dry metabolically active tissue (LDMAT), I subtracted the mass of the plumage, skeleton, and skin (and attached fat) from fresh body mass, assumed $67.5 \%$ water content for the remaining tissue (Piersma et al. 1999), and subtracted the total intramuscular fat content, derived as described above. Thus, LDMAT included the mass of all muscle, reproductive organs, digestive tract, and visceral organs (kidney, heart, liver, lungs, brain, pancreas, spleen, and endocrine glands). By subtracting the empirically determined values for total dry muscle mass and mass of the gut and gonads (the latter two both multiplied by 0.325 to account for water content), I obtained the dry mass of visceral organs (DMVO). 
Finally, I used dial calipers to measure the lengths of 16 skeletal elements (to the nearest $0.05 \mathrm{~mm}$ ). These included skull length and width, four structures associated with the bill (total mandible length and width, and dentary and premaxilla length), the three major long bones of the leg (femur, tibiotarsus, and tarsometatarsus), and wing (humerus, ulna, and carpometacarpus), and the coracoid. I then measured the maximum length of the sternum and maximum length and height of the keel.

Statistical analyses. - I used $t$-tests to compare mean values between the sexes (corrected for unequal variances when necessary). Size dimorphism was described through the use of Lovich and Gibbons' (1992) sexual-size-dimorphism index (SSDI), where 1.0 is subtracted from the quotient obtained from the division of the size of the trait in the larger sex by the size of the same trait in the smaller sex. Thus, an SSDI of 0.05 is equivalent to a $5 \%$ difference in size. I also performed separate principal component analyses (PCA) of the external linear measures of size and the skeletal elements to derive two composite measures of body size for each individual. Males and females were analyzed together, and the PCA of external characters was performed with and without keel length to evaluate whether including this infrequently measured character affected the results. Rising and Somers (1989) compared eight approaches for measuring multivariate size with PCA and showed that all served equally well. I therefore based the PCA on a correlation matrix that used the untransformed values for each character. Principal component analysis generally requires three to four observations for each variable included in the analysis, but generally performs better with a larger observation-to-variable ratio (McGarigal et al. 2000). I therefore used only 8 of the 16 skeletal elements for the PCA. These included two trophic characters (mandible length and width), two leg elements (tarsometatarsus and tibiotarsus), the two bones of the wing to which the remiges attach (ulna and carpometacarpus), and two body-core dimensions (keel length and depth). As indicated by the very high correlation between the first principal component (PC1) scores derived from the analysis of the reduced set and an analysis of the full set of 16 skeletal characters $(r=0.960, P<0.0001, n=54)$, very little information was lost by reducing the number of variables to eight. I also employed discriminant function analysis (DFA) to evaluate my ability to correctly classify individuals to sex using the external morphological characters.

Three males collected in May were exceptionally heavy $(\geq 50 \mathrm{~g})$ and may have been migrants. I therefore omitted those birds from analyses involving body mass. In addition, analyses involving fat content were limited to birds associated with nests, because every measure of fat content declined through May (all $P<0.001$ ), but then remained relatively constant during breeding. Muscle components showed no variation with date (all $P \geq 0.558$ ) and, therefore, all birds were used in analyses of muscle components. Statistical analyses were performed using STATISTIX, version 8 (Analytical Software, Tallahassee, Florida) and SPSS, version 10 (SPSS, Chicago, Illinois; DFA only). Sample sizes vary because of missing data or compromised samples, but in all cases I assumed statistical significance at $\alpha \leq 0.05$.

\section{Results}

Morphological comparisons. - Univariate comparisons suggested an absence of sexual size dimorphism in most characters, because male and female body mass, bill dimensions, and tarsus length were virtually identical (Table 1). Males exceeded females in wing chord and tail length (SSDI $=0.063$ and 0.062, respectively; Table 1), and especially keel length (SSDI = 0.097). At the skeletal level, none of the characters differed between the sexes except for the bones associated with flight (Table 2). Sternum and keel length, keel depth, coracoid length, and the bones that composed the wing were all significantly longer in males (Table 2). The SSDI of sternum and keel dimensions were again in the range of $0.10-0.11$, but the most extreme SSDI of the wing elements (ulna and carpometacarpus) was lower (0.040-0.045; Table 2).

All variables loaded positively on PC1 from the PCA of external characters; keel and bill length yielded the highest loadings, followed by wing chord and bill depth (Table 3). Birds with high scores on PC1 tended to be large in all measures of size. Principal component 2 described differences in bill width in relation to the lengths of the tail and wing. Thus, birds with negative scores had long tails and wings but narrow bills (and vice versa). Principal components 1 and 2 accounted for $>60 \%$ of the total 
TABLE 1. Comparisons of body mass (g), lengths $(\mathrm{mm}$ ) of external characters, and principal component (PC1 and PC2) scores of male and female Eastern Kingbirds collected in Kansas in 1983.

\begin{tabular}{lcccccc}
\hline \hline Character & Male (SD) & $(n)$ & Female (SD) & $(n)$ & $t(P)$ & SSDI $^{\text {a }}$ \\
\hline Body mass & $41.60(1.51)$ & 22 & $41.60(2.75)$ & 30 & $0.08(0.931)$ & 0.000 \\
Wing chord & $117.60(2.06)$ & 27 & $110.70(2.42)$ & 31 & $11.67(0.000)$ & 0.062 \\
Tarsus length & $19.10(0.627)$ & 27 & $19.14(0.681)$ & 31 & $0.22(0.826)$ & 0.002 \\
Tail length & $87.80(2.14)$ & 26 & $82.60(3.486)$ & 31 & $6.56(0.000)$ & 0.063 \\
Bill length & $14.14(0.645)$ & 27 & $13.82(0.746)$ & 31 & $1.76(0.084)$ & 0.023 \\
Bill width & $8.30(0.459)$ & 27 & $8.36(0.484)$ & 31 & $0.42(0.673)$ & 0.007 \\
Bill depth & $6.54(0.248)$ & 27 & $6.50(0.424)$ & 31 & $0.44(0.662)$ & 0.006 \\
Keel length & $28.20(1.04)$ & 26 & $25.70(1.15)$ & 31 & $8.32(0.000)$ & 0.097 \\
PC1 ("size") & $1.00(1.191)$ & 26 & $-0.86(1.451)$ & 31 & $5.21(0.000)$ & - \\
PC2 ("shape") & $1.00(0.884)$ & 26 & $-0.85(1.114)$ & 31 & $6.83(0.000)$ & - \\
PC1 ("size") & $0.36(1.340)$ & 26 & $-0.32(1.597)$ & 31 & $1.71(0.093)$ & - \\
PC2 ("shape") & $1.08(0.581)$ & 26 & $-0.93(0.954)$ & 31 & $9.77(0.000)$ & - \\
\hline
\end{tabular}

a SSDI = sexual size dimorphism index (see text).

${ }^{b}$ Analyses conducted with keel length included as a variable.

${ }^{c}$ Analyses conducted without keel length included as a variable.

TABLE 2. Variation in skeletal size among male $(n=25)$ and female $(n=28)$ Eastern Kingbirds, based on measurement of 16 characters, and average scores on first principal component (PC1) in PCA of skeletal traits (see text).

\begin{tabular}{lrrrr}
\hline \hline Character & \multicolumn{1}{c}{ Male } & \multicolumn{1}{c}{ Female } & & \\
$($ mean \pm SD) & $($ mean \pm SD) & SSDI \\
\hline Mandible length & $32.80 \pm 0.932$ & $32.71 \pm 0.960$ & $0.33(0.740)$ & 0.003 \\
Mandible width & $7.11 \pm 0.330$ & $7.12 \pm 0.341$ & $0.15(0.883)$ & 0.001 \\
Premaxilla & $11.89 \pm 0.496$ & $11.69 \pm 0.595$ & $1.34(0.187)$ & 0.017 \\
Dentary & $9.73 \pm 0.508$ & $9.60 \pm 0.589$ & $0.87(0.389)$ & 0.014 \\
Skull length & $40.55 \pm 1.068$ & $40.40 \pm 1.124$ & $0.52(0.604)$ & 0.004 \\
Skull width & $17.09 \pm 0.428$ & $17.21 \pm 0.386$ & $1.08(0.287)$ & 0.007 \\
Femur & $18.13 \pm 0.518$ & $18.02 \pm 0.465$ & $0.83(0.411)$ & 0.006 \\
Tibiotarsus & $29.70 \pm 0.786$ & $29.80 \pm 0.808$ & $0.47(0.640)$ & 0.003 \\
Tarsometatarsus & $18.47 \pm 0.549$ & $18.60 \pm 0.600$ & $0.83(0.408)$ & 0.007 \\
Sternum length & $28.00 \pm 1.000$ & $25.50 \pm 0.781$ & $10.22(0.000)$ & 0.098 \\
Keel length & $27.67 \pm 1.118$ & $24.93 \pm 0.889$ & $9.94(0.000)$ & 0.110 \\
Keel depth & $12.58 \pm 0.543$ & $11.37 \pm 0.444$ & $8.91(0.000)$ & 0.106 \\
Coracoid & $20.56 \pm 0.471$ & $20.17 \pm 0.490$ & $2.98(0.004)$ & 0.019 \\
Humerus & $24.71 \pm 0.518$ & $24.25 \pm 0.518$ & $3.17(0.003)$ & 0.019 \\
Ulna & $35.49 \pm 0.835$ & $34.08 \pm 0.652$ & $6.89(0.000)$ & 0.041 \\
Carpometacarpus & $16.80 \pm 0.433$ & $16.09 \pm 0.420$ & $6.06(0.000)$ & 0.044 \\
PC1 & $1.16 \pm 1.730$ & $-1.10 \pm 1.520$ & $5.06(0.000)$ & - \\
\hline
\end{tabular}

morphological variability (Table 3). Excluding keel length from the analysis resulted in greater contributions of all bill characters to PC1 and a stronger contribution by tarsus length (Table 3). Average body size (PC1) of males and females differed significantly when keel length was included as a variable, but not when it was omitted (Table 1). Regardless of the presence or absence of keel length, PC2 scores differed between the sexes (Table 1). A bivariate plot of PC1 and PC2 scores, based on the analysis that included keel length, demonstrated the near complete separation of the sexes (Fig. 1). Moreover, the DFA correctly classified $96.5 \%$ of individuals to sex $(100.0 \%$ of males and $93.3 \%$ of females) using four variables: wing chord (standardized-canonical-discriminant-function coefficient $[\beta]=0.694)$, keel length $(\beta=0.603)$, 
TABLE 3. Factor loadings for the first two principal components (PC1 and PC2) from the PCA of external characters of Eastern Kingbirds collected in Kansas. Analyses were conducted with and without keel length.

\begin{tabular}{|c|c|c|c|c|}
\hline \multirow[b]{2}{*}{ Character } & \multicolumn{2}{|c|}{ With keel length } & \multicolumn{2}{|c|}{ Without keel length } \\
\hline & PC1 & PC2 & PC1 & PC2 \\
\hline Bill depth & 0.368 & 0.268 & 0.483 & 0.021 \\
\hline Bill length & 0.441 & 0.298 & 0.540 & 0.078 \\
\hline Bill width & 0.326 & 0.466 & 0.481 & 0.311 \\
\hline Keel length & 0.454 & -0.286 & - & - \\
\hline Tail length & 0.321 & -0.480 & 0.168 & -0.678 \\
\hline Tarsus length & 0.328 & 0.270 & 0.420 & 0.103 \\
\hline Wing chord & 0.384 & -0.486 & 0.201 & -0.653 \\
\hline Eigenvalue & 2.589 & 1.841 & 2.246 & 1.634 \\
\hline Percentage of variation & 37.0 & 26.3 & 37.4 & 27.2 \\
\hline Cumulative percentage of variation & 37.0 & 63.3 & 37.4 & 64.6 \\
\hline
\end{tabular}

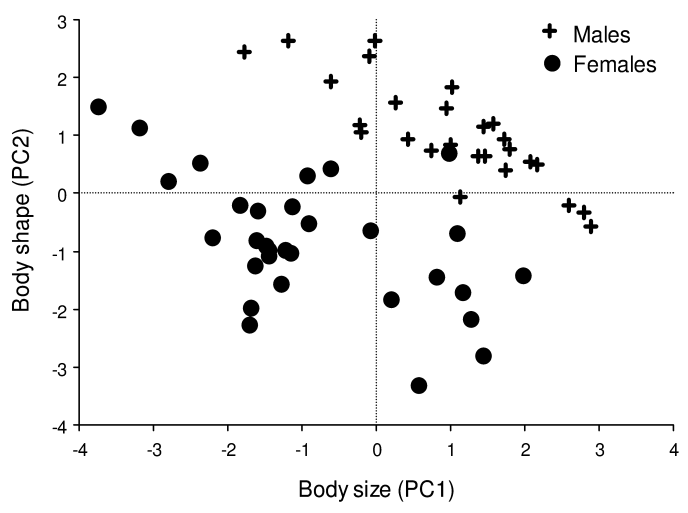

FIG. 1. Bivariate plot of PC1 scores ("body size") versus PC2 scores ("body shape") for male and female Eastern Kingbirds collected in eastern Kansas in 1983. Positive scores on PC1 indicate large body size. Body shape represents a contrast of birds with long tail and wing chord but narrow bills (negative scores) to individuals possessing short tails and wing chords but wide bills (positive scores).

tail length $(\beta=0.467)$ and bill depth $(\beta=-0.371)$. Females thus had shorter wings, keel and tail but, for their size, relatively deep bills.

Analysis of skeletal characters showed again that PC1 was a descriptor of body size. It accounted for $48.4 \%$ of morphological variability (eignenvalue $=3.874$ ), with the strongest contributions coming from the ulna (factor loading $=0.469$ ) and carpometacarpus (0.426), followed by keel length (0.377) and depth (0.349), and mandible (0.334) and tibiotarsus
(0.328) lengths. Contributions by tarsometatarsus length (0.296), and especially mandible width (0.169), were relatively low. Males had significantly higher scores on PC1 than females (Table 2), and PC1 estimates of body size from the analyses of external characters (keel length included) and skeletal elements were highly correlated $(r=0.825, P<0.001)$. Separate analyses of males $(r=0.709, P<0.001)$ and females $(r=0.783, P<0.001)$ were significant. Thus, standard morphological data taken in the field yielded reliable estimates of body size on the basis of measurement of skeletal characters.

Body composition. - Male and female plumage and skeletal mass were very similar (Table 4 ) and averaged $7.7 \%(\mathrm{SD}=0.84, n=48)$ and $4.0 \%$ of wet body mass ( $\mathrm{SD}=0.35, n=51)$, respectively. On the other hand, most other variables exhibited substantial differences between the sexes. The mass of the reproductive system and skin plus subcutaneous fat were greater in females than in males (SSDI $\geq 0.421$; Table 4). The SSDI for gut and LDPMM both approached 0.30 and indicated that females had substantially heavier guts but proportionally smaller pectoral muscles than males (Table 4). The LDTMM was also greater in males (Table 4). In general, females carried more subcutaneous and intramuscular fat (Table 4), but because male muscle mass was greater, the absolute amount of intramuscular fat carried by the sexes was the same (Table 4).

Male and female LDMAT were nearly identical $($ SSDI $=0.014)$ because of the different but balanced distribution of tissue to organs and muscle groups. The DMVO, the mass of tissue 
TABLE 4. Comparisons of body composition of male and female Eastern Kingbirds collected from eastern Kansas during the 1983 breeding season.

\begin{tabular}{|c|c|c|c|c|c|c|}
\hline Character & Male (SD) & $n$ & Female (SD) & $n$ & $t(P)$ & SSDI \\
\hline Plumage mass (g) & $3.42(0.462)$ & 25 & $3.34(0.402)$ & 27 & $0.68(0.500)$ & 0.024 \\
\hline Skeletal mass (g) & $1.74(0.124)$ & 25 & $1.68(0.154)$ & 28 & $1.57(0.122)$ & 0.036 \\
\hline Gonads (g) & $0.42(0.219)$ & 19 & $0.68(0.588)$ & 25 & $2.02(0.052)$ & 0.619 \\
\hline Gut (g) & $3.74(0.666)$ & 24 & $4.77(0.880)$ & 28 & $4.70(0.000)$ & 0.275 \\
\hline Skin and fat $(\mathrm{g})^{\text {a }}$ & $0.76(0.361)$ & 19 & $1.08(0.306)$ & 25 & $3.18(0.003)$ & 0.421 \\
\hline LDPMM (g) & $4.98(0.430)$ & 23 & $3.86(0.379)$ & 28 & $9.92(0.000)$ & 0.290 \\
\hline PMM fat $(\%)^{\mathrm{a}}$ & $6.21(1.120)$ & 19 & $7.46(1.750)$ & 25 & $2.85(0.007)$ & 0.201 \\
\hline Fat $(P M M)(g)^{a}$ & $0.33(0.070)$ & 19 & $0.31(0.082)$ & 25 & $0.92(0.361)$ & 0.064 \\
\hline LDTMM (g) & $7.68(0.577)$ & 23 & $6.24(0.555)$ & 28 & $9.01(0.000)$ & 0.231 \\
\hline TMM fat $(\%)^{a}$ & $7.15(1.690)$ & 19 & $8.54(1.720)$ & 25 & $2.67(0.011)$ & 0.194 \\
\hline Fat $(\mathrm{TMM})(\mathrm{g})^{\mathrm{a}}$ & $0.59(0.144)$ & 19 & $0.58(0.127)$ & 23 & $0.35(0.728)$ & 0.017 \\
\hline $\operatorname{LDMAT}(\mathrm{g})$ & $10.84(0.550)$ & 22 & $10.99(0.812)$ & 27 & $0.76(0.454)$ & 0.014 \\
\hline Observed DMVO (g) & $1.84(0.346)$ & 22 & $2.98(0.530)$ & 27 & $9.07(0.000)$ & 0.620 \\
\hline Predicted DMVO $(\mathrm{g})^{\mathrm{b}}$ & $1.51(0.044)$ & 22 & $1.52(0.078)$ & 27 & $0.65(0.516)$ & - \\
\hline
\end{tabular}

Abbreviations: sexual-size-dimorphism index (SSDI), lean dry pectoral muscle mass (LDPMM), pectoral muscle mass (PMM), lean dry total muscle mass (LDTMM), total muscle mass (TMM), lean dry metabolically active tissue (LDMAT), and dry mass of visceral organs (DMVO).

a Based on breeding birds collected after May.

b See text.

unaccounted for by direct measurement of muscle and the reproductive system and digestive tract represented the mass of vital organs (heart, lung, kidney, liver, brain, spleen, and endocrine glands, plus the crop). Observed DMVO was determined by subtraction, but I also calculated a predicted DMVO using each bird's body mass and prediction equations (from Peters 1984) for each of the first five organs listed above. Predicted DMVO of males was significantly less than observed DMVO $(t=$ 4.34, $P<0.001)$, but given that observed DMVO also included other components (see above), predicted and observed DMVO were close. On the other hand, observed DMVO of females was much greater than both their predicted value $(t=14.21, P<0.001)$ and the observed male DMVO (Table 4).

Scaling of pectoral muscle mass. - The coefficient of variation (CV) of LDPMM exceeded that of all measures of external sizes (Fig. 2) and lengths of skeletal elements (male mean $\mathrm{CV}=$ 3.23, range: $2.10-5.22$; female mean $\mathrm{CV}=3.25$, range: 1.92-6.13). The LDPMM was not only the most variable character measured, it also accounted for nearly two-thirds of the entire muscle mass of males $(64.8 \%, \mathrm{SD}=1.32, n=$ 25). Female LDPMM constituted only a slightly lower proportion of TMM $(61.8 \%, \mathrm{SD}=1.47, n=$ $28)$, but the difference was significant $(t=8.00$,

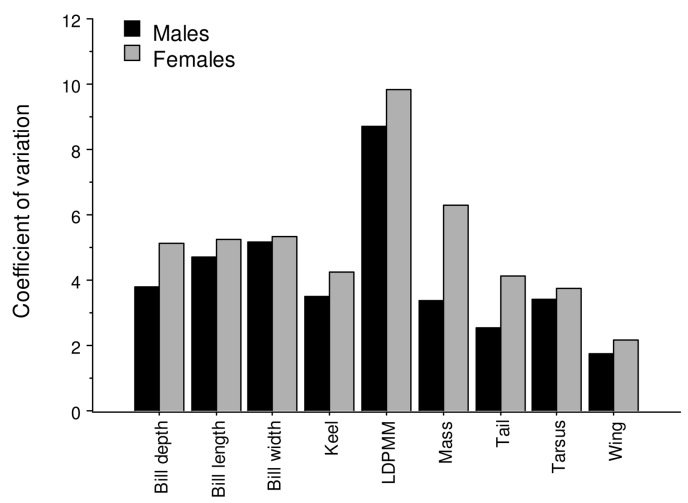

FIG. 2. Comparisons of coefficients of variation for eight external measures of size and lean dry pectoral muscle mass (LDPMM) of male $(n=$ 22-25) and female $(n=27-30)$ Eastern Kingbirds collected in Kansas in 1983.

$P<0.001, n=49)$. Least-squares regression of log LDPMM against log body mass demonstrated that LDPMM increased with total body mass in both males $\left(r^{2}=0.365, P=0.003\right)$ and females $\left(r^{2}=\right.$ $0.565, P<0.001$ ), and the exponents (i.e., slopes) of the male $(1.57 ; 95 \%$ CI: 0.606 to 2.534$)$ and female equations (1.19; 95\% CI: 0.759 to 1.619$)$ fell above 1.0 (Fig. 3). But, given the 95\% CI, the sexes differed neither from each other nor from an isometric slope of 1.0. On the other hand, the 


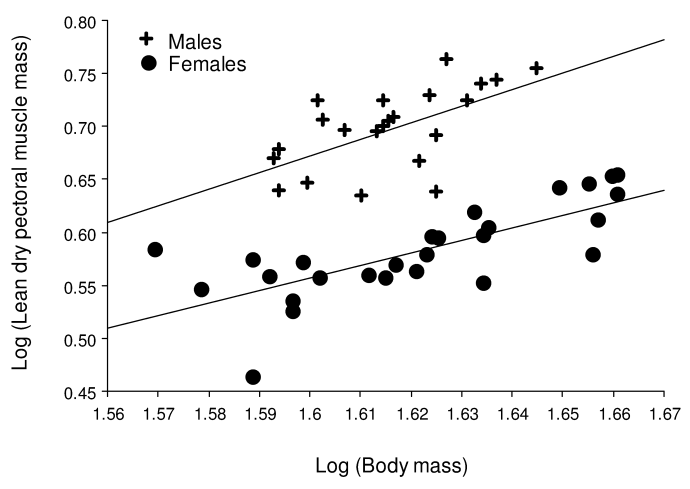

FIG. 3. Log-log plot of lean dry pectoral muscle mass against body mass for 22 male and 27 female Eastern Kingbirds. Power equations based on least-squares regression produced statistically identical slopes for males (LDPMM = 0.014 [body mass $\left.]^{1.574}\right)$ and females $($ LDPMM $=$ 0.045 [body mass] $\left.{ }^{1.1890}\right)$, but the reduced major axis slope of males was significantly higher than that of females (see text).

coefficient (i.e., elevation of line) of males was significantly greater than that of females (analysis of covariance: $F=197.2, P \ll 0.001$; Fig. 3), which indicates that after controlling for body size, male PMM was substantially greater than that of females.

Obtaining error-free estimates of body mass is essentially impossible, given measurement error and variability associated with both diurnal and seasonal changes. Least-squares-regression methods underestimate slope when the independent variable is measured with error. Therefore, I used reduced major axis regression to generate more accurate estimates of the slope of log LDPMM against log body mass (see Sokal and Rohlf 1981). As expected, the slopes of both males (2.61; 95\% CI: 1.642 to 3.578) and females (1.58; $95 \%$ CI: 1.150 to 2.010$)$ increased, but the increase was greater among males. The lack of overlap of the $95 \% \mathrm{CI}$ of the sexes with one another, and with a value of 1.0, indicated that LDPMM increased faster with body mass in males than in females, and that both sexes exhibited positive allometry for LDPMM.

\section{Discussion}

The SSDI of wing chord and tarsus length differ between socially monogamous and polygynous species. As a general rule, wing chord is only $\sim 5 \%$ larger in males, on average, than in females in socially monogamous species (Price 1984a, Promislow et al. 1992, Webster 1992, Delestrade 2001, Kissner et al. 2003). The SSDI of tarsus is close to zero in socially monogamous species (Webster 1992, Delestrade 2001, Regosin and Pruett-Jones 2001), and the SSDI for Eastern Kingbird wing chord (0.062) and tarsus length (0.002) fell well within the range for socially monogamous passerines. Congeneric Scissor-tailed Flycatchers (T. forficatus) have extremely sexually dimorphic tail lengths (SSDI $=0.47$ ), but wing dimorphism (SSDI $=0.09$; Regosin and Pruett-Jones 2001) falls within the range for socially monogamous passerines. Other characters typically used to assess sexual size dimorphism (body mass, bill dimensions) also suggested that male Eastern Kingbirds were, at best, only slightly larger than females. Also, PC1, a commonly used estimator of body size, did not differ between the sexes unless keel length was included as a variable. However, the more detailed body-composition analysis told a different story. Males and females differed in many important respects, and on the basis of these characters are, without question, sexually dimorphic. The SSDI for keel length, TMM, and PMM were 0.097, 0.231 and 0.290, respectively, all greater in males. On the other hand, the SSDI of the gut was much greater in females (0.275), females carried relatively more fat than males, and female DMVO was nearly twice that of males (Table 4).

Differences in muscle mass were especially striking (Fig. 3), and the largest males carried nearly $100 \%$ greater LDPMM than the smallest females. This was attributable to both the greater overall male muscle mass and more rapid increase of LDPMM with body mass in males. Skeletal mass did not differ between the sexes, but the lengths of the skeletal elements associated with flight were longer in males (Table 2). Taken as a whole, males possess longer skeletal elements and muscles associated with flight and, compared with females, appear to be designed for flight performance. On the other hand, females store more fat and, with their larger alimentary tract, seem especially well suited for the rapid processing of food.

The sexual differences in muscle mass, skeletal dimensions, apparent digestive capacity, and fat storage represent an unequivocal example of cryptic sexual size dimorphism and suggest 
distinctly different selection pressures operating on the sexes. Males and females undertake the same migratory flights, and no evidence exists for sexual differences in social structure during the nonbreeding season (Morton 1971). I suggest that cryptic sexual size dimorphism has evolved in response to two interrelated, and possibly inseparable, breeding-season phenomena. First, although Eastern Kingbirds are socially monogamous, females alone build the nest and take the lead in feeding the young. Males establish territories and are the primary defenders of the nest throughout the nest cycle (Woodard and Murphy 1999). Low overall body mass may reduce the cost of the frequent flights made by females as they build nests and attend to young. Territory and nest defense potentially favor individuals who are able to generate rapid and agile flights. Thus, selection may favor powerfully built males with large flight muscles.

However, Eastern Kingbirds also have a cryptic polygamous breeding system in which $>50 \%$ of males lose paternity of the young in their nest (Rowe et al. 2001, Dolan et al. unpubl. data). The high skew in male reproductive success creates substantial opportunities for sexual selection (Dolan et al. unpubl. data), and female choice, of both within-pair and extrapair sires, may be based at least in part on flight performance. Large PMM may thus be a sexually selected character. Lean dry pectoral muscle mass was the most variable character that I measured (in both sexes), exceeding even body mass, which suggests that flight performance may be equally variable and may be used to assess mate quality (as Regosin and Pruett-Jones [2001] suggested for tail length in Scissor-tailed Flycatchers). Petrie (1988) and Green (1992) argued that sexually selected traits should exhibit positive allometry in species in which either competitive or display ability determines mating success, and this was the case in Eastern Kingbirds. It is possible that both phenomena-selection for division of parental roles and sexual selection for flight performance-may act in concert to generate or sustain (or both) current levels of size dimorphism. Establishing a primary role for either natural or sexual selection will require a thorough analysis of ancestral states and evolutionary trends within the Tyrannidae.

The only other studies, to my knowledge, that provide data of similar detail are Hammond et al.'s (2000) study of Red Junglefowl (Gallus gallus) and Chappell et al.'s (1999) analysis of House Sparrows (Passer domesticus). In comparison with those species, Eastern Kingbirds seem more like Red Junglefowl, in that gut mass is substantially greater in females of both species, whereas muscle mass is greater in males (larger leg muscles in Red Junglefowl and larger pectoral muscles in Eastern Kingbirds). Female House Sparrows had larger gizzards than males, but the major difference between the sexes in the latter species was larger liver and kidney mass in females. The PMM values of males and females were nearly identical in House Sparrows and Gray Catbirds (Dumetella carolinensis; Marsh 1984). More data are needed to evaluate whether body composition differs between the sexes in other sexually monomorphic species. Therefore, I do not claim that Eastern Kingbirds are exceptional. But the differences that exist must be recognized, and such species should be classified as cryptically sexually size dimorphic. Muscle mass affects aerobic demands, power output, and behavioral performance (e.g., Marsh 1984, Chappell et al. 1999, Hammond et al. 2000, Veasey et al. 2000, Kullberg et al. 2002) and, as shown here, muscle mass can exhibit far greater dimorphism than the support surfaces that are usually measured to characterize sexual size dimorphism.

It is, no doubt, impossible to resolve the issue of how best to measure sexual dimorphism in body size. A major reason for this is the different motivations for the use of this variable, and certainly the question being asked should dictate the measure chosen. The use of wing chord and tarsus length as proxies of size has probably arisen for their ease of measurement, but the fact that the degree of sexual size dimorphism of both characters varies with mating system (see above) indicates that biologically useful information is conveyed. Nonetheless, the revolution in our understanding of mating patterns of socially monogamous species, which has occurred only during the past decade (reviewed by Griffith et al. 2002), establishes the need for the use of other, potentially more meaningful, measures of size to evaluate mate choice and the opportunity for sexual selection for species with more subtle variation in mating patterns. Rates of extrapair paternity and cryptic sexual size dimorphism are very high in Eastern Kingbirds. Tree Swallows, well known for their very high rates of extrapair paternity (e.g., Whittingham et al. 2003), also 
exhibit cryptic sexual size dimorphism: PMM is greater in males than in females (Burness et al. 1998). Although it is potentially only coincidental in these two species, I predict that the degree of cryptic sexual size dimorphism will ultimately be shown to correlate positively with levels of cryptic polygamy among socially monogamous passerine birds.

\section{Acknowledgments}

I dedicate this paper to the memory of Marion Jenkinson. She taught me museum techniques, helped mentor me, and saw to it that I was gainfully employed as a curatorial assistant at the Museum of Natural History at the University of Kansas. She was also a friend who offered advice about ornithology, professionalism, and life.

\section{Literature Cited}

Burness, G. P., R. C. Ydenberg, and P. W. НоснАснкА. 1998. Interindividual variability in body composition and resting oxygen consumption rate in breeding Tree Swallows, Tachycineta bicolor. Physiological Zoology 71: 247-256.

Calder, W. A., III 1984. Size, Function, and Life History. Harvard University Press, Cambridge, Massachusetts.

Chappell, M. A., C. Bech, and W. A. Buttemer. 1999. The relationship of central and peripheral organ masses to aerobic performance variation in House Sparrows. Journal of Experimental Biology 202:2269-2279.

DaAn, S., D. Masman, and A. Groenewold. 1990. Avian basal metabolic rates: Their association with body composition and energy expenditure in nature. American Journal of Physiology 259:R333-R340.

DARwin, C. 1871. The Descent of Man and Selection in Relation to Sex. Reprint, Princeton University Press, Princeton, New Jersey 1981.

Delestrade, A. 2001. Sexual size dimorphism and positive assortative mating in Alpine Choughs (Pyrrhocorax graculus). Auk 118: 553-556.

Diamond, J. M. 1975. Assembly of species communities. Pages 342-444 in Ecology and Evolution of Communities (M. L. Cody and J. M. Diamond, Eds.). Belknap Press of Harvard University Press, Cambridge, Massachusetts.

Downhower, J. F. 1976. Darwin's finches and the evolution of sexual dimorphism in body size. Nature 263:558-563.

Green, A. J. 1992. Positive allometry is likely with mate choice, competitive display and other functions. Animal Behaviour 43:170-172.

Griffith, S. C., I. P. F. Owens, and K. A. Thuman. 2002. Extra pair paternity in birds: A review of interspecific variation and adaptive function. Molecular Ecology 11:2195-2212.

Hammond, K. A., M. A. Chappell, R. A. Cardullo, R.-S. Lin, And T. S. Johnson. 2000. The mechanistic basis of aerobic performance variation in Red Junglefowl. Journal of Experimental Biology 203:2053-2064.

Johnston, R. F., And R. C. Fleischer. 1981. Overwinter mortality and sexual size dimorphism in the House Sparrow. Auk 98: 503-511.

Johnston, R. F., And R. K. Selander. 1971. Evolution in the House Sparrow. II. Adaptive differentiation in North American populations. Evolution 25:1-28.

Kissner, K. J., P. J. Weatherhead, and C. M. FrancIs. 2003. Sexual size dimorphism and timing of spring migration in birds. Journal of Evolutionary Biology 16:154-162.

Kullberg, C., N. B. Metcalfe, and D. C. Houston. 2002. Impaired flight ability during incubation in the Pied Flycatcher. Journal of Avian Biology 33:179-183.

Lovich, J. E., AND J. W. GibBons. 1992. A review of techniques for quantifying sexual size dimorphism. Growth, Development, and Aging 56:269-281.

Marsh, R. L. 1984. Adaptations of the Gray Catbird Dumetella carolinensis to longdistance migration: Flight muscle hypertrophy associated with elevated body mass. Physiological Zoology 57:105-117.

McGarigal, K., S. Cushman, and S. Stafford. 2000. Multivariate Statistics for Wildlife and Ecology Research. Springer-Verlag, New York.

Monaghan, P., and D. N. B. Metcalfe. 1986. On being the right size: Natural selection and body size in the Herring Gull. Evolution 40: 1096-1099.

Morton, E. S. 1971. Food and migration habits of the Eastern Kingbird in Panama. Auk 88: 925-926. 
Murphy, E. C. 1985. Bergmann's Rule, seasonality, and geographic variation in body size of House Sparrows. Evolution 39:1327-1334.

Murphy, M. T. 1986. Body size and condition, timing of breeding, and aspects of egg production in Eastern Kingbirds. Auk 103:465-476.

Peters, R. H. 1983. The Ecological Implications of Body Size. Cambridge University Press, Cambridge, United Kingdom.

Petrie, M. 1983. Female moorhens compete for small fat males. Science 220:413-415.

Petrie, M. 1988. Intraspecific variation in structures that display competitive ability: Large animals invest relatively more. Animal Behaviour 36:1174-1179.

Piersma, T., L. Bruinzeel, R. Drent, M. Kersten, J. Van Der Meer, and P. Wiersma. 1996. Variability in basal metabolic rate of a long-distance migrant shorebird (Red Knot, Calidris canutus) reflects shifts in organ size. Physiological Zoology 69:191-217.

Piersma, T., G. A. Gudmundsson, and K. LilliendaHL. 1999. Rapid changes in the size of different functional organ and muscle groups during refueling in a long-distance migrating shorebird. Physiological and Biochemical Zoology 72:405-415.

Piper, W. H., and R. H. Wiley. 1989. Correlates of dominance in wintering White-throated Sparrows: Age, sex and location. Animal Behaviour 37:298-310.

Price, T. D. 1984a. The evolution of sexual size dimorphism in Darwin's Finches. American Naturalist 123:500-518.

Price, T. D. 1984b. Sexual selection on body size, territory and plumage variables in a population of Darwin's Finches. Evolution 38:327-341.

Promislow, D. E. L., R. Montgomerie, and T. E. Martin. 1992. Mortality costs of sexual dimorphism in birds. Proceedings of the Royal Society of London, Series B 250:143-150.

Radford, A. N., and M. A. Du Plessis. 2004. Extreme sexual dimorphism in Green Woodhoopoe (Phoeniculus purpureus) bill length: A case of sexual selection? Auk 121: 178-183.

Regosin, J. V., and S. Pruett-Jones. 2001. Sexual selection and tail-length dimorphism in Scissor-tailed Flycatchers. Auk 118:167-175.

Rising, J. D., AND K. M. Somers. 1989. The measurement of overall body size in birds. Auk 106:666-674.
Robinson, S. K., AND J. Terborgh. 1995. Interspecific aggression and habitat selection by Amazonian birds. Journal of Animal Ecology 64:1-11.

Rowe, D. L., M. T. Murphy, R. C. Fleischer, AND P. G. Wolf. 2001. High frequency of extrapair paternity in Eastern Kingbirds. Condor 103:845-851.

SÆTHER, B.-E. 1989. Survival rates in relation to body weight in European birds. Ornis Scandinavica 20:13-21.

SoKal, R. R., AND F. J. Rohlf. 1981. Biometry: The Principles and Practice of Statistics in Biological Research, 2nd ed. W.H. Freeman, San Francisco, California.

Székely, T., J. D. Reynolds, and J. Figuerola. 2000. Sexual size dimorphism in shorebirds, gulls, and alcids: The influence of sexual and natural selection. Evolution 54:1404-1413.

Temeles, E. J., I. L. Pan, J. L. Brennan, and D J. N. Horwitt. 2000. Evidence for ecological causation of sexual dimorphism in a hummingbird. Science 289:441-443.

Veasey, J. S., D. C. Houston, and N. B. Metcalfe. 2000. Flight muscle atrophy and predation risk in breeding birds. Functional Ecology 14:115-121.

WAGNER, R. H. 1999. Sexual size dimorphism and assortative mating in Razorbills (Alca torda). Auk 116:542-544.

Webster, M. S. 1992. Sexual dimorphism, mating system and body size in New World blackbirds (Icterinae). Evolution 46:16211641.

Whittingham, L. A., P. O. Dunn, and E. D. Clotfelter. 2003. Parental allocation of food to nestling Tree Swallows: The influence of nestling behaviour, sex and paternity. Animal Behaviour 65:1203-1210.

Wiley, R. H. 1974. Evolution of social organization and life-history patterns among grouse. Quarterly Review of Biology 49:201-227.

Woodard, J. D., and M. T. Murphy. 1999. Sex roles, parental experience and reproductive success of Eastern Kingbirds, Tyrannus tyrannus. Animal Behaviour 57:105-115.

Zаммuто, R. M. 1986. Life histories of birds: Clutch size, longevity, and body mass among North American game birds. Canadian Journal of Zoology 64:2739-2749.

Associate Editor: H. F. James 